\title{
Neologisms formation using borrowed affixes in the Russian Internet segment
}

\author{
Anna Belkova ${ }^{1, *}$ \\ ${ }^{1}$ Nizhnevartovsk State University, Academic Department of Philology and Mass Communication, \\ 628602, 56 Lenina str., Nizhnevartovsk, Russia
}

\begin{abstract}
The aim of this article is to define the specific features of the neologisms used on the Russian websites. Online media texts contain a lexical set that makes it possible to demonstrate the features of the neologisms. The most numerous group of the neologisms with borrowed affixes comprises $56 \%$ of neologisms that are formed by the means of prefixes or prefixoids, and $44 \%$ of neologisms that are formed by the means of suffixes or suffixoids. Online media discourse is an effective space for a language-game, for that reason this subject provides a vast field for research. The modern concept of a new word consists of the broad understanding of neologisms as the new words, definitions and set expressions, that are based on the perception of relativity of the term «new» as well as on the understanding of neologisms as a sociohistorical category. The formation and substitution of the old words by the new ones is one of the most dynamic processes in the modern Russian language that provokes an academic interest in the modern linguistics. With regard to the above mentioned, the specific reasons for the relevance of neologisms research in the grammatical agent terms are represented in two main principles: the extralinguistic principle and the intralinguistic principle. The idea of the extralinguistic principle is in the nature of a fast-changing community that is in a permanent need for creating new definitions for themselves in the new social roles and professional features. The idea of the intralinguistic principle is in the permanent need for systematization of productive means of the new words formations, establishing synchronic segments of major activity of certain word-forming patterns and marking the contrary tendencies of productivity decline [1-2].
\end{abstract}

The strong interest of many decades is still present concerning the research of the new words, their consistency and the anomalies of their formation. The issues of neologisms are covered by the linguists from Russia and many other countries, among those linguists are V. G. Gak, O. D. Meshkov, V. I. Zabotkina, R. A. Budagov, L. A. Hakham, E. R. Rozen, G. N. Alieva, T. V. Maksimova, Y. A. Muradyan, L. Gilbert, D. Crystal, S. L. Cutler, Y. A. Murzabulatova, V. Tsinsyan and so on [3-7].

This article reveals the specific features of neologisms functioning using affixes in the Russian Internet segment by the example of NoNaMe website.

* Corresponding author: bae14@mail.ru 
The main causes of the neologisms formation on the NoNaMe website are the following: the necessity of naming new subjects and concepts that enter the life of modern society as well as the necessity of giving new names to certain things that have already had names, and the intention to define certain known things with just one word instead of the periphrasis. For this reason, online media uses the specific set of linguistic means on the phonetic, lexical, word formation, morphological and syntactic levels of the language, these means are used in different linguistic styles as well.

The analyzed website NoNaMe is an Information Portal, and it is hosted at nnm.me. This is a major website, that is organized as a multilevel combination of different resources and services that are updated in real-time. NoNaMe website features a significant amount of content, and the website is designed to work under large load capacities. Websites of this type are designed with a complex structure, and they feature interactive services.

The aim of the NoNaMe information portal is to help users find the necessary information regarding certain subjects. It is quite easy to navigate this website, as it is useful and effective, because of the special features all the data on this website is easily structured and systematized.

NoNaMe is a public web portal. The website was created in 2000 and it offers a significant range of online services, such as communication services, content posting, documents implementation, commenting, polls, discussions and so on.

The NoNaMe website features include the main page and 12 topic sections. The main page features link to those sections as well as the news. The content of this website is both educational and entertaining. Users of this website can find a significant amount of interesting things for themselves, anything from up-to-date news to the latest movies releases.

The examination has revealed that the website defines communication system of online relations both in written and spoken forms. The website records the contemporary language, and displays the language patterns of its users; thus representing significant information sources of linguistics system perception of the Russian language of the first half of 21 st century.

The topic model of this website is represented by a selection of articles. The subject of the magazine is assorted, the articles presented feature business, industry-based and infromational orientation. The magazine serves the interests of its target audience by providing an insight into the technological and engineering innovations; the magazine promotes advanced experience and serves as a means of internal discussions concerning the economics, politics and so on.

Currently, the issue of neologisms usage on websites is gaining significance, particularly the study of word-formation activity. The articles of the NoNaMe website feature a certain lexical set that makes it possible to detect the condition of lexical and word-formation systems of the contemporary Russian language. This lexical set also makes it possible to display the features of neologisms.

Word-formation in the contemporary Russian language concerns the study of the words structure and the principles of their organization. Russia's academic specialists that study derivatology focus their attention on the formation of the new words by the means of root and affixational morphemes compounding as well as the non-affixal means. The items of word-formation means are represented by different compounds of derivative words based on the root or formant organization [8-9].

A study was conducted concerning the neologisms using NoNaMe website as an example as per the aim of this research. The analyzed linguistic items, that are formed by the means of borrowed affixes fall into the following subgroups:

a) prefixes/prefixoids: super-, psevdo [pseudo] -, de-, eks [ex]-, mega-, top-, non-, antiand so on. For example, superstar, psevdosfera [pseudosphere], demotivator 
[demotivational poster], eks-predchuvstvie [ex-feeling], nonfakt [nonfact], nonfiguralnyi [non-figural], antiglamurnyi [anti-glamorous], antidempingovyi [anti-dumping] and so on.

Super-prefix (denotes superior form or action of something): supertranslyaciya [superbroadcast], superprovokaciya [super-provocation], superstar and so on. For example, «My podnyalis $\mathrm{v}$ ofis, gde po televideniyu beschislennoe kolichestvo raz povtoryalas supertranslyaciya etih kadrov Apokalipsisa [We entered the office room, and the TV kept super-broadcasting the images of apocalypse over and over]». «V 80 -e gody slovo «superprovokaciya» u podavlyayushchego bolshinstva grazhdan prochno associirovalos $\mathrm{s}$ zarubezhnymi turisticheskimi poezdkami [During the 80s a lot of people associated the word super-provocation with touristic overseas trips]». «Vozmozhno, eti sluhi raspuskal politicheskiy huligan Anton Bakov, superstar «lihih devyanostyh [Perhaps, these rumors were spread by a political tough Anton Bakov, the super star of the wild '90s]» [10-11].

Psevdo [pseudo] - prefix (false, fictitious): psevdodokument [pseudo-document], psevdogeishi [pseudo-geishas], psevdorealiti-shou [pseudo-reality show], psevdo-lichnost [pseudo-personality], psevdoreligiya [pseudo-religion], psevdoduhovnost [pseudospirituality]. For example, «Dmitriy Medvedev pishet: «Vybrav v kachestve formy psevdodokument [Dmitry Medvedev writes the following: «Chosen pseudo-document as a type of form»]». «Sovremennye psevdogeishi svyato blyudut kanony professional'noj ehtiki, unasledovannye ot ih ehkzoticheskih predshestvennic [Contemporary pseudogeishas attend scrupulously to the canons of professional ethics that were inherited from their exotic predecessors]». «Realnye pacany»: Demonstrativno provincialnyj (permskii) serial, sdelannyi v zhanre psevdorealiti-shou, glavnye roli v kotorom ispolnyayut, po suti, neprofessionalnye aktery [«Cool dudes» (a famous Russian tv-show) is an ostentatiously provincial (Perm based) tv-show in the pseudo-reality show genre, the main roles are played by non-professional actors]». «Buddizm otricaet sushchestvovanie lichnosti ili zhe sushchestvuet vse zhe nekaya «psevdo-lichnost» [Buddhism denies the existence of a personality or there is still some kind of «pseudo-personality»]». «Ya so vsei siloi oshchushchayu, chto odna iz glavnyh opasnostej vsegda i vsyudu - psevdoreligiya, psevdoduhovnost [I have a strong feeling that one of the main threats everywhere you go is pseudo-religion, pseudo-spirituality]» [10-11].

De-prefix (it is used in the verbs and verbal nouns to demonstrate cancellation or denial of something): deblokirovat [deblock], depromoushn [depromotion] and so on. For example, «Odnovremenno Belyi dom pytaetsya deblokirovat vozmozhnosti dlya polucheniya evropeiskimi stranami realnoj samostoyatelnosti ... [In the meantime, The White House is trying to deblock the abilities for the European countries to get real independence ...]». «Depromoushn salona krasoty: 101 sposob sdelat salon neuspeshnym i nepopulyarnym [Depromotion of a beauty salon: 101 ways to make an unsuccessful and unpopular beauty salon]». «Depromoushn akcii i predvybornyh agitacionnyh kompanii [Depromotion of stock shares and electoral campaign]» [10-11].

Eks [Ex]-prefix (it is used to form words to give them the definition of «preceding or former»: eks-Menuhin [ex-Menuhin], eks-Oistrah [ex-Oistrakh], eks-Spivakov [exSpivakov], eks-kapitan [ex-captain], eks-futbolist [ex-footbakk player], eks-glava [ex-head], eks-izdatel [ex-editor] and so on. For example, «Starye instrumenty, na kotoryh igrali velikie, nazyvayutsya «eks-Menuhin» ili «eks-Oistrah». Navernoe, kogda-nibud eta skripka budet nazyvatsya «eks-Spivakov [Old instruments of great musicians are called «ex-Menuhin» or «ex-Oistrakh». Perhaps, this violin will be called «ex-Spivakov» someday]». «Eks-kapitan sbornoi Italii, nyne glavnyi trener «Guanchzhou» (KNR) Fabio Kannavaro prigovoren k 10 mesyacam tyurmy za narushenie sudebnogo zapreta [Excaptain of Italy national football team, currently the head coach of «Guangzhou Evergrande» Fabio Cannavaro was sentenced to 10 months of imprisonment for breaking the court order]». «Eks-futbolist «Barselony» i «Reala» portugalec Luish Figu vydvinul 
svoyu kandidaturu [Ex-football player of «Barcelona» and «Real Madrid» Luís Figo filed his candidacy]». «Eks-glava YUKOSa - tenevoj vygodopriobretatel ot likvidacii soratnika po oppozicionnomu dvizheniyu [Ex-head of Yukos Oil Company is a shadow gain acquirer from the elimination of his companion within the opposition movement]». «Vidimo, odnim iz pervyh eto ponyal eks-izdatel, do sovsem nedavnih por klyuchevaya figura $\mathrm{v}$ mire delovoi literatury Mihail Ivanov [Apparently, one of the first people to understand this was an ex-editor Mikhail Ivanov, until quite recently he was the key person in the business literature sphere]» [10-11].

The prefix «eks- [ex]» gives the definition of «preceding or former» to a word it is used with; thus forming neologisms.

Mega-prefix (it forms the words to give them the definition of «big, enormous sizes»): mega-proekt [megaproject], mega-akciya [mega-event], megamarket [megastore], megafanat [mega-fan]. For example, «Nedavno stalo izvestno, chto etot mega-proekt vklyuchen v obnovlennuyu «transportnuyu strategiyu RF do 2030 goda [It was found out just recently that this megaproject was included into the renewed «Transport strategy of Russia until $2030 »] »$. «Tak, chtoby poehat v super-, mega- ili gipermarket i nabrat tam produktov na vsyu nedelyu, ne zhivet nikto [Nobody goes to a supermarket, megastore or a hypermarket to buy a lot of food for the entire week]». «Esli ty mega-fanat Halfy - velkam, a ostalnym predlagayu dozhdatsya normalnogo reliza [If you're a mega-fan of the Half-Life video game, then welcome, as for the rest of the people, I advise you to wait for a better release]» [10-11].

Top-prefix (it forms the words to give them the definition of «being one of the best or popular»: top-menedzher [top manager], top-prodazha [top-sale], top-komplektaciya [toppackage], top-lot and so on. For example, «Podavlyayushee bolshinstvo oproshennyh topmenedzherov zayavili o tom, chto rashody ih kompanii na autsorsing vozrastut $\mathrm{v}$ techenie 2018 goda [A large majority of surveyed top managers said that the outsourcing expenses of their companies will increase over the course of 2018]». «Poetomu vazhno postoyanno zanimatsya razrabotkoi novyh produktov, kotorye bystro popadut $\mathrm{v}$ top-prodazh [That is why it is important to keep developing new products that will eventually be in the list of top-sales]». «Nam na test dostalsya samyi dorogoi Sportage: dvuhlitrovyi dizel, topkomplektaciya "premium" [We got the most expensive Sportage for a test, it is 2.0-liter diesel-engined of «premium» top-package]». «Sredi top-lotov - abstraktnoe polotno Barnetta Nyumana «Chernyi ogon I» (84 mln. dollarov) [Among the top-lots of the auction is Barnett Newman's «Black Fire I» on canvas ( $\$ 84$ mil), the display of the abstract expressionism]» [10-11].

Non- prefix (it forms the words to give them negative definition): non-fikshn [nonfiction], non-fud [nonfood], non-komformizm [nonconformism] and so on. For example, «Imenno poetomu za nachalnicei otdela «non-fud» prochno zakrepilos prozvishhe "Lara Kroft" [That's exactly why the head of the nonfood department got the nickname "Lara Croft"]». «Hochetsya bolshe sereznogo non-fikshn o nesereznom [We want more serious nonfiction about light-hearted things]». «V otlichie ot literatorov potencialnye avtory non-fikshn mogut rasschityvat na sereznoe povyshenie svoego professionalnogo i dazhe mediynogo statusa [Unlike the regular writes, nonfiction authors can expect a serious promotion of both occupational and media statuses]». «Kak by to ni bylo, k chesti gimnazii - moj yunyj non-komformizm ili stroptivost nikakix posledstvij dlya menya ne imela [Anyway, the nonconformism or stubbornness of my adolescence did not affect the reputation of the grammar school]» [10-11].

Anti- prefix (it forms the words with the definition of contradiction): anti-kot [anti-cat spray], antilaik [anti-like], anti-rezhim [anti-regime], anti-formalna [anti-formal] and so on. For example, «Est eshhe "anti-kot" - spreevoi ballonchik s fotoelementom, reagiruyushim na dvizhenie [There's also "anti-cat" this is a spray with a photoelectric cell that reacts to 
movements]». «Fotke dayu antilaiki [I would give this photograph an anti-like]». «Ya ne pro to, chto nado pozu anti-rezhim, ili kontru-kakuyu vystavlyat dlya obostreniy i vovlecheniy [I'm not talking about some anti-regime posture, or some some sort of counterrevolutionary features that are designed to fuel the situation or an engagement of some sort]». «Mezhdu tem ta "pravda", kotoruyu predpolagaet socrealisticheskoe proizvedenie, predelno anti-formalna [Anyway, the sort of "truth" that is intended by the social realistic product is very anti-formal]» [10-11].

Contemporary researchers note the following prefixes as the ones that are the most common in the texts: sverh- [extra-], super-, anti-. It is also worth mentioning the following foreign-language prefixes that form neologisms: nano-, multi-, bio- and so on.

Nano- prefix (from Greek «nanos»-dwarf; it forms the words with the definition of «one billionth»): nanotehnologiya [nanotechnology], nanopilyulya [nanopill] and so on. For example, «Tolkacheva ne pereoformlyayut arendnyh dogovorov bez predyavleniya platezhki o pozhertvovanii na HHS, eto, konechno, ne skazat, chtoby nanotexnologiya [They wouldn't re-issue Tolkachev's lease contract until he shows them a payment document that would prove the fact that he's made a donation to the Cathedral of Christ the Saviour, well, which isn't necessarily a nanotechnology]». «Dlya etogo nuzhno razrabotat sovershenno bezopasnyi dlya cheloveka variant maloi RNK, chtoby nanopilyulya s etim preparatom postoyanno tsirkulirovala $\mathrm{v}$ krovi [In order to do this, a completely safe for a human model of small RNA must be developed, so that the nanopill with this product could circulate in the blood stream permanently]» [10-11].

The aforementioned examples demonstrate the prefixal types of the neologisms that as a whole represent «contemporary and progressive technologies of the latest generation».

Multi-prefix (it forms the words to give them the definition of "plurality or multiplicity of something»): multisplitsistema [multi split system], multimodalnyi [multimodal], multitreiler [multi-trailer] and so on. For example, «V etom sluchae vam nuzhno otkazatsya ot mnozhestva vneshnih blokov i vybrat multisplitsistemu, imeyushuyu tolko odin vneshniy blok [In this case, you need to abandon the idea of a set of outdoor units, and get a multi split system instead with just one outdoor unit]». «V sostave etogo terminala predusmotreno sozdanie multimodalnogo logisticheskogo centra s perevalkoi konteinerov na rechnoi, zheleznodorozhnyi i avtomobilnyi transport [The development of a multimodal logistics center is planned within this airport terminal, this center will serve as a transshipping point to transfer the cargo to sea, railroad and automobile transport]». «Multitreiler BMW vypolnen v stile aktualnyh modelei avtomobilei toi zhe marki [BMW multi-trailer is made in the modern style of the cars of the same brand]» [10-11].

Bio-prefix (from ancient Greek «life»; it forms the words with the definition of «life related»): biodata, biopasport [biopassport], biometricheskii [biometric] and so on. For example, «Chto bylo, v sushnosti, neudivitelno - sistema dolzhna byla reshat meditsinskie problemy sozhitelnitsy opirayas na ee sobstvennuyu biodatu [Well, it didn't come as a surprise, since the system should have solved the medical problems of the roommate relying on the roommate's own biodata]». «Menya nastorazhivaet eshe i tot fakt, chto posrednicheskaya kontora raspolagaetsya sovsem ryadyshkom s upravleniem, tak skazat, dlya udobstva strazhdushih bystro oformit biometricheskiy dokument [This fact is rather suspicious that a commission business facility is just a short distance away from the department for the people who desperately want to get a biometric document]» [10-11].

b)Suffixes / suffixoids: -ing, -izm, -atsiya, -izatsi(ya), -ist, -ik, -i, -a,-ost, -ov, -sk, -ichesk, -er, -ist, -ling-tion and so on. For example, parking, eskapizm [escapism], franchaizing [franchising], rebrending [rebranding], dzhiping [jeeping], reraiter [rewriter], rekruter [recruiter], startaper [startupper] and so on.

-Ing suffix: riforming [reforming], treiding [trading], franchaizing [franchising], merchendaizing [merchandising], parking, rebrending [rebranding], dzhiping [jeeping], 
vending. Recently, the English affix «-ing» became more substantive. The generative basis comprises nouns that received the following semantics once they received the «-ing» affix: the semantics of equivalence, procedural semantics and similarity semantics. For example, «V neftepererabotke est takoi kompleksnyi process - kataliticheskii riforming (on sluzhit $\mathrm{v}$ osnovnom dlya polucheniya aromaticheskih soedinenii iz benzina i ligroina) [There's a generic process in the oil processing, this process is called catalytic reforming (it serves to extract the aromatic compounds from the gasoline and naphtha)]». «Mi reshili ne delat stavku na robotizirovannyi treiding [We decided not to bank on the robot-assisted trading]». «Mnogie izvestnye firmy, vo vsem mire praktikuyushie franchaizing, u nas poka ne speshat doverit svoi brend drugim ili delayut eto $\mathrm{v}$ individualnom $\mathrm{i}$ neformalizovannom poryadke [Many famous companies that work on a franchising principle do not trust Russian entrepreneurs just as much to use their brands, and even if they go for it, they do it on an individual or nonformalized basis]». «Distributsiya, logistika, merchendaizing, navyki menedzherov i prodavtsov imeyut, navernoe, dazhe bolshee znachenie $\mathrm{v}$ etom dele [Perhaps the following features have a bigger value in this business: distribution, logistics, merchandising, managers and sellers skills]». «Esli vy puteshestvuete na avtomobile, prezhde chem snyat nomer, stoit pointeresovatsya, est li pri otele parking [If you're traveling by a car, you'd better ask if the hotel has a parking lot before booking a room there]». «Pervonachalnyi mestnyi tirazh gazety, rebrending kotoroi byl proveden $v$ nachale etogo goda, sostavit 10 tys. ekzemplyarov [A local newspaper that had a rebranding at the beginning of this year will be printed in 10 thousand copies]». "Ya ne znayu, kak u nih tam vse poluchilos, no k utru dzhiping semenovskogo papashi sgorel $\mathrm{v}$ garazhe [I'm not exactly sure what happened, but Semenov father's jeeping got burnt down in the garage by the morning]». «Avtomaty, rabotayushhie na zerne, chasto pokupayut te, kto hotel by sdelat vending dopolnitelnym prirabotkom k osnovnomu biznesu [Usually, those who want to get some extra cash in addition to their main business install a coffee vending machine]» [9].

-Izm suffix: eskapizm [escapism] and so on. For example, «Eskapizm yavlyaetsya faktorom i dlya knigoizdatelskoi otrasli [Escapism is one of the factors of publishing sphere as well]».

Besides that, the Russian segment contains a significant amount of the following suffixal nouns: -atsiya/-izatsiya, -ik, -ist, -ost; For example, dollarizaciya [dollarization], byudzhetnik [low-cost], kollazhist [collagist], kontseptualist [conceptualist], geteroseksualnost [heterosexuality]; as well as the following adjectives with the suffixes of -n, -(ov)sk; For example, kagebeshnyi [KGB-related], halyavnyi «poluchennyi darom ili za chuzhoi schet» [«freebee» - something recieved for free or at someone else's expense], goskomstatovskii [State Statistics Service related], samizdatovskii [self-publish books related], nornikelevskii [Nornickel-related] and so on [10-11].

-Atsiya/-izatsiya suffix: dollarizatsiya [dollarization], fetishizatsiya [fetishization], yuridizatsiya [juridification], immunizatsiya [immunisation] and so on. For example, «U nas, mezhdu prochim, voobshhe proizoshla povalnaya dollarizatsiya strany [Among other things, our country underwent a full dollarization]». «I snova meshaet etomu neglasnoe otozhdestvlenie psihologii $\mathrm{s}$ eksperimentalnym metodom, ego fetishizatsiya [His fetishization again gets in the way of an unspoken identification of psychology with the experimental approach]». «Yuridizatsiya i racionalizatsiya Hristovoi istiny i est perehod s puti svobody na put prinuzhdeniya [The juridification and the rationalization of Christ's message is the transition from the way of freedom to the way of compulsion]». «Krome planovoi vakcinatsii sushhestvuet i ekstrennaya profilaktika kleshhevogo encefalita immunizatsiya, to est povyshenie immuniteta $\mathrm{k}$ virusu [Besides the scheduled vaccination there's also a special preventive measure from the tick-borne encephalitis, it's called the immunization i.e. the immunity improvement against the virus]» [10-11]. 
-Ik suffix: byudzhetnik [low-cost] and so on. For example, «Imenno hodovaya vkupe so sverhprostornym salonom i nemalenkim bagazhnikom prevrashhaet etot sedan v idealnyj dacha-kar - nadezhnyi i vmestitelnyi byudzhetnik dlya semeinyh razezdov [Just because of its undercarriage, a really spacious interior and a big trunk this sedan turns into a perfect countryside car, it's a safe and spacious low-cost car for the family rides]» [10-11].

-Ist suffix: kollazhist [collagist], kontseptualist [conceptualist], brovist [brow stylist], vizazhist [makeup artist], stilist [stylist] and so on. For example, «Edinstvennyi kollazhist i edinstvennyi emocionalnyi vsplesk etoi podcherknuto otricayushei vsyakie proyavleniya manernoi «hudozhestvennosti» vystavki [This exhibition denies any display of «art» mannerism featured the only collagist that also turned out to be the only emotional outburst of this exhibition]». «Horosho i polno predstavleny $\mathrm{v}$ kollektsii konceptualist Viktor Skersis, Boris Orlov, Erik Bulatov [The following conceptualists are well and fully presented in this collection: Viktor Skersis, Boris Orlov, Erick Bulatov]». «Nedarom prestizhnoi professiei sredi molodyh lyudei stali manikyurshik i brovist [It comes as no surprise that some of the prestige jobs among young people are manicure makers and brow stylists]». «Ideyu voploshhaet, kak pravilo, tselaya komanda: vizazhist, dizainer, parikmaher, stilist [The ideas are usually fulfilled by the entire team: a makeup artist, a designer, a hairdresser, a stylist]» [10-11].

$-N$ suffix: kagebeshnyi [KGB-related], halyavnyi [freebee] and so on. For example, «Otklyuchit povsemestno vodu meshaet kagebeshnyi chin v boilernoi, a v kvartiru etu, chto zalivaet nizhnie etazhi, ne prorvatsya [A kgb-related man does not allow us to turn the water off in the boiler room, and also we cannot enter the flat where the water comes from and floods all the lower floors]». «Hotel na dezhurstve, kak prilichnyi, ne halyavnyi bolnichnyi sahar grizt, a svoi [I just wanted to act decent during my duty, and I wanted to eat my own sugar, instead of the hospital freebee one]» [10-11].

-A suffix: izomerizatsiya [isomerization], modernizatsiya [modernization], garmonizatsiya [harmonization], unifikatsiya [unification], optimizatsiya [optimization], kombinatsiya [combination], kapitalizatsiya [capitalization] and so on. The structure of the words that belong to this model of word formation carries the information about the origins of a word, as the words are formed with a Latin suffix -a. For example, «Vektornaya optimizatsiya v proektirovanii slozhnyh izdelii na primerah vybora variantov reaktivnogo dvigatelya [Vector optimization of the development of sophisticated products as exemplified on the jet engine options choice]». «Unifikatsiya metadannyh - eto ispolzovanie obshih sredstv opisaniya informacionnyh resursov: klassifikacionnyh shem, slovarei terminov i opredelenii, tezaurusov predmetnyh oblastei, kodifikatorov dannyh i metadannyh [Meta data unification is the usage of the common means of the definition of informational resources: classification schemes, vocabularies interpreting terms and notions, thesaurus of subject terms, data and meta data codificators]». 《Garmonizaciya standartov na urovne gosudarstv - neobhodimaya mera podderzhki rossiiskogo eksportera [The harmonization of the standards on the state level is a necessary measure of support the Russian exporters]» [10-11].

-Ost suffix: likvidnost [liquidity], fiskalnost [fiscal], rentabelnost [commercial viability] and so on. Noun suffix -ost features specific productivity, as it possess the characteristic of the abstract features and the ability to provoke an action. For example, «Izbytochnaya likvidnost kak raz ne daet rynku provalitsya dostatochno gluboko [The excessive liquidity keeps the market at an acceptable level]». "Ya poluchal fiskalnost s ulichennogo polovinu shtrafa [I received the fiscal matters regarding my fine]». «Prozvuchali cifry, chto rentabelnost proekta sostavlyaet $157 \%$ [I've heard that the project's commercial viability will be at $157 \%] »[10-11]$.

-(Ov)sk suffix: samizdatovskii [self-publish books-related], nornikelevskii [Nornickelrelated], putinskii [Putin's], strategicheskii [strategic], brokerskii [broker], trampovskii 
[Trump's] and so on. For example, «Sidya na podokonnike, ona chitaet kakoi-to samizdatovskii shedevr: inogda zevaet, inogda sosredotochenno smotrit v storonu [She is sitting on a window sill, reading some self-published masterpiece, sometimes she yawns, sometimes she looks away and looks at something with concentration]». «Mozhno predstavit sebe, kak ego vosprinyali lyudi, kotoryh cherez chetyre goda putinskii preemnik mozhet vraz snyat so svoih postov [You can just imagine how they accepted him, those people who may lose their jobs in four years' time if the Putin's successor wills so]». «Tak chto zhe, ves «nornikelevskii» sobachatnik deistvitelno pokoitsya na printsipe, imeya lish kosvennoe otnoshenie k dengam? [So what does it mean, the entire Nornickel mob just acts under some principles and doesn't have a direct connection to the money?]» «On sumel ispolzovat dlya svoei lichnoi vygody strategicheskii povorot kitaiskogo rukovodstva $\mathrm{k}$ sozdaniyu innovacionnoj ekonomiki [He managed to use China's strategic turn to innovative economy for his own benefit]». «Dostatochno vsego lish otkryt brokerskii schet po torgovle na mezhdunarodnyx rynkah [You only need to open a broker account for the world market trading]». «Tolko chto postroennyi trampovskii otel, kak on sam sebya reklamiruet, «samyi prestizhnyi adres v mire [Trump's recently built hotel, as he himself advertises it "the most prestigious address in the world"]» [10-11].

-Ichesk suffix: kataliticheskii [catalytic]. This suffix is the equivalent of -esk suffix. When it is stressed and added to the base of the nouns, it forms adjectives with the meaning of characteristic and relatedness to the motive words that are represented by the common names. For example, «Obrazuyushhiesya dymovye gazy napravlyayutsya v kataliticheskii filtr - tam proishodit nizkotemperaturnoe okislenie nesgorevshih ostatkov organicheskih soedinenii [The formed combustion gases are transported into the catalytic reactor, then the low-temperature oxidation of unburnt organic compounds occurs there.]» [10-11].

It is worth noting that the adjective terms with the suffix are represented by -sk, -esk, ichesk morhpemes and feature the common definition of «related to or common to what is called the motive word».

Neologisms formation occurs less often with the suffixes -er, -ist, -ling; For example, Netzwerker (das Netzwerk - network), a computer professional engineer who is also a technician of communications system installations. Tagger (German - taggen; English - to tag) a graffiti artist. Alarmist (from German der Alarm) - a person that exaggerates some events, talks about the wrong development of our society.

As it can be seen, the new formations in the contemporary language system of the Internet space are the display of active processes in the sphere of word-formation. Quantitative analysis revealed the plethora of neologisms in the language that illustrates, first of all, the wide variety of words that are used in the contemporary media texts. Second of all, it illustrates the intention of the writers to display the reality in a more flexible manner, in the semantic, stylistic, descriptive and the other means.

As it was covered in this research, the most significant group of neologisms with borrowed affixes on the NoNaMe website comprises the following:

- 56\% of neologisms are formed with the following prefixes or prefixoids: super-, psevdo- [pseudo], de-, eks [ex]-, mega-, top-, non-, anti- and so on.

- $44 \%$ of neologisms are formed with the following suffixes or suffixoids: -ing, -izm, atsiya/-izatsiya, -ist, -ik, -i, -a, -ost, -ov, -sk, -ichesk, -er, -ist, -ling-tion and so on.

As it can be seen, the formations in the contemporary language system are the display of active processes in the word-formation sphere, related to the adaptive function of the Russian language (borrowed lexical items undergo the adaptation process, by the means of word-formation in the first place). Considering the aforementioned facts, Internet media discourse is an active space for a language-game, and the neologisms are the means of realization of this game. The process of neologisms formation and the updating of the 
Russian language is not over and it continues permanently, that is why this subject represents a vast field for the future researches.

\section{References}

1. M. N. Shansky, Lexicology of modern Russian language (2007)

2. L. O. Butakova, Morphemics and word formation (2012)

3. G. Brown, G. Yule, Discourse Analysis (Cambridge University Press, 1983)

4. S. Brunet. Dou ca vient? Inventaire etymologique du francais quotidian (2000)

5. M. T. Cabre, Et al. L'observatoire de neologie: conception, methodologie, resultats et nouveaux travaux, Innovation lexicale, (2003)

6. J. A. Murzabulatova, Neologisms with the value of the worker in the modern Russian language: press the end of XX beginning of XXI century (2013)

7. V. Zinsen. Russian neologisms-universe: methods of education, semantics, features of functioning, PhD, candidate, (2016)

8. A. E. Belkova, International Research Journal, 11(42), Part 4, pp. 8-11 (2015)

9. A. E., Belkova, Plotkin A. A, Young Scientist, 31133 (2016)

10. The public information portal NoNaMe (http://nnm.me, 2018)

11. Dictionary of neologisms. URL: http://slovar-neologizmov.html (2018) 